\title{
IMPLICAÇÕES PÓS-COLONIALISTAS NA OBRA DE JOSÉ CRAVEIRINHA: UM POVO ENTRE A CRUZ E A ESPADA
}

\author{
André Boniatti \\ (Universidade Estadual do Oeste do Paraná)
}

\section{RESUMO}

José Craveirinnha é mormente considerado em sua pátria, Moçambique, seu maior expoente literário, tal qual Camões o é em Portugal, em virtude de ter sido defensor de suas letras e de ter lutado contra a submissão de sua Nação. Sua poesia demarca resistência e imarcescível lirismo, não se reduzindo apenas ao protesto. A universalidade de seus versos alcança seus pares, povos submetidos à imposição cultural e a um processo de aculturação impossível de ser realizado por completo. No presente artigo, busca-se relacionar sua verve poética com os estudos pós-colonialistas, tentando trazer à tona absurdos da colonização e a tentativa superação de tal realidade, ainda presente em nosso pensamento, a ser descolonizado. Refletem-se aqui, pois, acerca de poemas como "África", "Grito negro", "Poema do futuro cidadão", entre outros, transparecendo o brilho e a genialidade de seu autor.

PALAVRAS-CHAVE: José Craveirinha, Pós-colonialismo, Poesia.

\section{ABSTRACT}

José Craveirinnha is especially regarded in his homeland, Mozambique, his greatest literary exponent, such as Camões in Portugal, by the virtue of had defended their language and have fought against the submission of their Nation. His poetry is marked by resistance and unfading lyricism, not only reduced to protest. The universality of his verse reaches his brothers, people undergoing cultural imposition and a process of acculturation, impossible to be completely performed. In the present article is related his poetic verve with postcolonial studies, trying to show the colonization's absurdities and the attempt to overcome this reality, still present in our thinking, to be decolonized. It's reflected here in poems like "África", "Grito negro", "Poema do futuro cidadão", among others, transpiring the brightness and the genius of its author.

KEYWORDS: José Craveirinha, Postcolonialism, Poetry. 
A poesia de José Craveirinha é um ato político, em primeira instância. Muito embora haja sua poesia lírica tênue e dócil, como a de sua obra saudosista "Maria”, e a poesia à flor da pele de seus poemas eróticos, o veio mais forte a demarcar seus escritos socialmente está em sua inserção à luta anticolonialista, desde a guerra da independência de Moçambique até à temática constante do racismo, que o discriminaria. A aparente simplicidade que dá cor a muitos dos seus versos tange, sobretudo, à profundidade com que seu povo se obscurece frente à imposição cultural instituída por Portugal, mediante o processo civilizatório. Deveras, essa antinomia entre o conceito de civilização e primitividade (conceito maniqueísta), deflagrada pelo branco europeu até aonde este pôde alcançar, deslinda o propósito do canto de muitos povos à força subjugados, como o deste poeta.

Norbert Elias (1990) transita entre os conceitos de cultura e civilização, deixando-nos assim entender, acerca de sua definição, que

[...] o conceito de civilização minimiza as diferenças nacionais entre os povos: enfatiza o que é comum a todos os seres humanos ou - na opinião dos que o possuem - o que deveria sê-lo. Manifesta a autoconfiança de povos cujas fronteiras nacionais e identidade nacional foram tão plenamente estabelecidos, desde séculos, que deixaram de ser tema de qualquer discussão, povos que há muito se expandiram fora de suas fronteiras e colonizaram terras muito além delas. (ELIAS, 1990, p. 25)

Acerca desse conceito, sua manutenção dá-se avidamente perante o propósito da dominação entre raças; mais próximo de nosso artigo: entre o europeu e o africano, este submetido a um processo quisto como de aculturação, diante da crença em seu erro e a imposição de sua bestialidade, num processo de alienação sociocultural que o leva ao subsolo da cidadania. Tal qual afirma Walter Mignolo,

En realidad, la conciencia criolla era más bien una doble conciencia: la de no ser lo que se suponía que debían ser (es decir, europeos). Ese ser que es en verdad un no-ser es la marca de la colonialidad del ser. Los afrocriollos y los aborígenes no tienen ese problema. En su caso, la conciencia crítica surge de no ser considerados ni siquiera humanos. ${ }^{1}$ (MIGNOLO, 2005, p. 87)

Mignolo está falando da América Latina; a asserção que faz da permanência social do indígena e do negro leva-nos a entender como a história portou-se a seu respeito. Tal comportamento evidencia revoltosas manifestações por todo o mundo e uma insistência criminosa, que está ainda longe de se encerrar, visto o racismo não dar mostras de extinguir-se até aos dias de hoje. Deveras, há países ainda passando por esse inacreditável estado de sujeição; ou melhor, mesmo em todas as antigas colônias (tal qual nas metrópoles) o ranço ainda é frequente, forte e desonesto, compreendendo ainda um sujeitamento racial de superioridade e inferioridade, sob o absurdo de uma conceituação maniqueísta, como acima já dito. 
Homi K. Bhabha, em O local da cultura, fala de Frantz Fanon, exclusivamente num de seus capítulos, e assim o deslinda:

A demanda de Fanon por uma explicação psicanalítica emerge das reflexões perversas da virtude civil nos atos alienantes do governo colonial: a visibilidade da mumificação cultural na ambição declarada do colonizador de civilizar ou modernizar o nativo, que resulta em "instituições arcaicas inertes [que funcionam] sob a supervisão do opressor como uma caricatura de instituições anteriormente férteis"; a validade da violência na própria definição do espaço social colonial; a viabilidade das imagens febris, fantasmáticas, do ódio racial, que serão absorvidas e encenadas na sabedoria do Ocidente. Essas interposições, na verdade colaborações, da violência política e psíquica no interior da virtude cívica, a alienação no interior da identidade, levam Fanon a descrever a cisão do espaço da consciência e da sociedade coloniais como marcada por um "delírio maniqueísta". (BHABHA, 1998, p. 75)

Esse ato de violência pensada, proposital, movido pela soberba entre povos, conduz a humanidade a séculos de atrocidades inexplicáveis e inexplicadas, senão pela suposição de erro, como acima dito, atribuído pelos católicos europeus, sob o nome de pecado, a todos os que transgredissem seus limites, no Ocidente ou Oriente. E é desse contexto, pois, que nasce a poesia de Craveirinha, sufocada por tais premissas e engasgada em sua garganta.

Daí não se poder divisar sua pessoa da história política de Moçambique, muito embora sua obra tenha uma peculiaridade estética que lhe legou uma permanência acima da simples poesia de protesto, muitas vezes banalizada ou desgastada. Entretanto, a força que o impele num primeiro momento é, deveras, o moto político, visto a colônia portuguesa em Moçambique estar em questionamento por seu povo. Como intelectual, Craveirinha vê-se movido a juntar-se à luta e bradar contra a submissão.

Seu país, em 1964, inicia a luta armada contra as forças de Portugal, estendendo-a até 1974, e conquistando enfim sua independência em 1975, sob negociação, após a derrocada do regime salazarista em consequência da Revolução dos Cravos. Datam desse período duas de suas obras: de 1964, Xibugo², com cantos de revolução e superação de tal realidade submissa; de 1974, Karingana ua Karingana (Era uma vez), que parece refletir uma retomada cultural, um retorno às origens de seu povo, contra a submissão cultural que devorava suas vidas. As datas das publicações, que demarcam também o período de maior tensão entre Portugal e a terra do poeta em questão, tornam-se antológicas em relação ao movimento de libertação efetuado. E desse veio ficam poemas notórios, como "África", ode de desobediência à pátria impostora que lhes impõe a aculturação.

Deveras, cada estrofe do poema denuncia veemente as feridas que encravam a alma moçambicana, estendendo-se universalmente a todos os 
povos que sofreram tais mazelas, bem como o país aqui abordado. Típico da voz de Craveirinha, que parece nela incluir a voz geral de seu povo, a mais que moçambicano, seu povo negro, como o diz em seu "Poema do futuro cidadão":

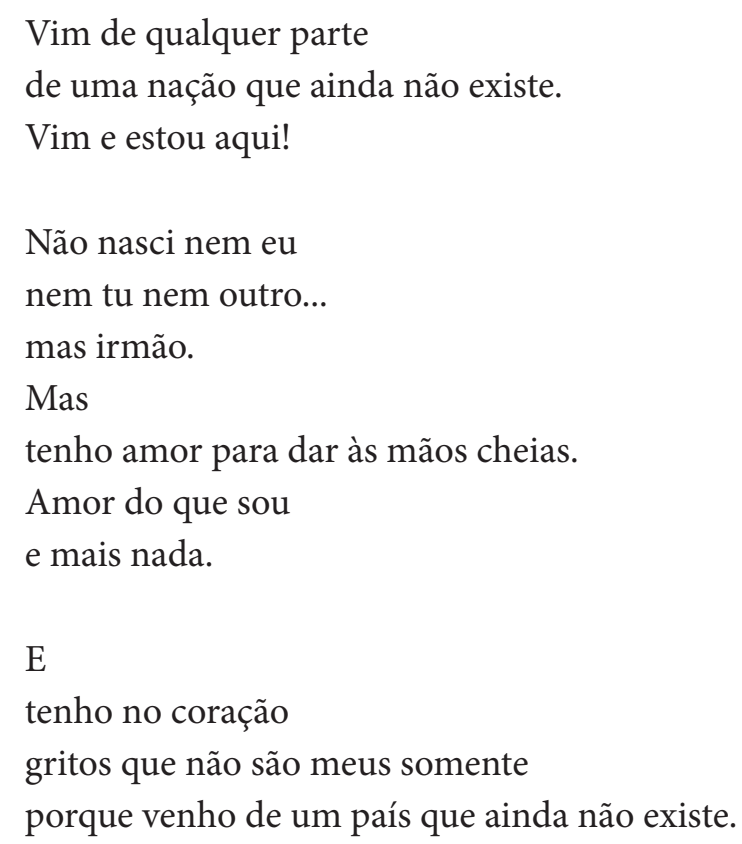

Ah! Tenho meu Amor a todos para dar do que sou.

$\mathrm{Eu}$ !

Homem qualquer

cidadão de uma Nação que ainda não existe.

(CRAVEIRINHA, 2010, p. 19)

Nos versos acima, pertencentes a Xibugo, é louvável a visão utópica do poeta, que prevê um momento de redenção entre raças, considerando-as irmãs; ou melhor, considerando os homens como raça única. É claro que isso só ocorreria a partir da compreensão das diferenças, pois não poderá propor que as crenças e a cultura de um e de outro sejam modificadas. E por isso afirma o amor do que é, não a transformação de um ou outro em um terceiro estado, em um ser impossível, que depõe suas passadas raízes para a transformação social. Por isso, também, fala de uma Nação a que ainda não pertencemos, uma Nação inexistente, não a julgando impossível, no entanto (porque está viva em seus sonhos).

Em “África”, agora o retomando, ele tratará contrariamente da sua atual realidade desde as raízes do impropério; sua primeira constatação nesse sentido é, portanto, a deportação de sua linguagem original a segundo plano:

Em meus lábios grossos fermenta a farinha do sarcasmo que coloniza minha Mãe África e meus ouvidos não levam ao coração seco misturada com o sal dos pensamentos a sintaxe anglo-latina de novas palavras. (CRAVEIRINHA, 2010, p. 16). 
Claramente, a língua é o primeiro indício de identificação cultural. Quando imposta sua substituição por uma outra, que ao falante é estranha, a beleza interior da pronúncia torna-se corrupta, mesmo o aparelho fonador lhe é estranho. Assim, o coração torna-se seco ao som da sua pronúncia. O sal dos pensamentos, ou seja, o tempero, a beleza, o encantamento que ocorre entre a organização linguística abstrata do pensamento e a memória afetiva, torna-se, em submissão, alheio, desgostoso, já que não há correlação pacífica entre a mnêmica (mesmo que sonhada, devaneada) e a realidade material atual do que se pensa e se profere. Dessa forma, a alma, enquanto repositório das vivências e sensações vividas, torna-se retraída, pois passa a pertencer a uma cultura estrangeira, estranha. Depois de tal afirmação, então, a denúncia desse estado terceirizado de sua alma obrigada adensa-se:

\begin{abstract}
Ajoelham-me aos pés dos seus deuses de cabelos lisos e na minha boca diluem o abstracto sabor da carne de hóstias em milionésimas circunferências hipóteses católicas de pão.
\end{abstract}

E em vez de meus amuletos de garras de leopardo vendem-me sua desinfectante benção (...)

Efígies de Cristo suspendem ao meu pescoço em rodelas de latão em vez dos meus autênticos mutovanas da chuva e da fecundidade das virgens do ciúme e da colheita de amendoim novo. (CRAVEIRINHA, 2010, p. 16 e 17)

Deflagra-se, assim, a imposição religiosa católica, regendo seu comando como a pecadores, tal qual se afirmará mais adiante em "civiliza o mau casto impudor africano" (CRAVEIRINHA, 2010, p. 17): nesse último verso citado, percebe-se a que se deve a obrigação, pois o povo de África é considerado promíscuo, justamente por ser considerado também primitivo, em oposição ao conceito de civilização, já ao princípio deste artigo considerado. Ora, ao opor o cidadão africano ao cidadão civilizado, propõe-se a correção de seu modus vivendi, por ser, mais do que impróprio, oposto aos desígnios do Deus cristão católico.

Deveras, à sociedade cristã, determinada pelo Império Romano em expansão, deu-se ao propósito do progresso, hoje burguês, que desconsiderou toda a cultura vivida anteriormente ou externamente ao que o catolicismo pregaria. Cria-se a imagem de que há um modelo de correção a ser aplicado - a salvação do mundo - e depõe-se contra tudo o que vá de encontro à Igreja, promotora dessa salvação. Portanto, como a cultura e a religião não se dissociam, em especial nas sociedades mais primitivas, quando os ritos evidenciam-se sem separação da vivência cotidiana (não pertencendo apenas ao templo, pois o mundo pagão é habitado por divindades), as sociedades anticristãs devem ser submetidas a um processo de correção, sob a palavra de Deus, interpretada a esse tempo pelo catolicismo. Não obstante sejam ignorados como seres humanos, sob argumentos 
ditos divinos, tal qual a interpretação dada à expulsão de Cam, filho de Noé, ${ }^{3}$ apenas ignorá-los não basta; é necessário colocar-lhes rédeas, proibir-lhes o pecado ou a prática de suas raízes culturais, pecaminosas. Se, por um lado, como Mignolo (2005) nos diz, não são nem sequer humanos, por outro, há que se justificar sua desumanização, por motivos para os quais encontramos bom subsídio em Jean-Paul Sartre, quando prefacia edição de Os condenados da terra, de Frantz Fanon: "uma vez que ninguém pode sem crime espoliar seu semelhante, escravizá-lo ou matá-lo, eles dão por assente que o colonizado não é o semelhante do homem" (SARTRE, in FANON, 1979, p. 9). E Sartre prossegue falando sobre o colonizador:

Esse personagem arrogante, enlouquecido por todo o seu poder e pelo medo de o perder, já não lembra realmente que foi um homem: julga-se uma chibata ou um fuzil; chegou a acreditar que a domesticação das "raças inferiores" se obtém através do condicionamento de seus reflexos. Negligencia a memória humana, as recordações indeléveis [...]. (SARTRE in FANON, 1979, p. 11.)

Dessa maneira, a suposta superioridade racial do branco se impõe sobre África, soberbamente, com o intuito de coibir definitivamente sua humanidade. Mas impossível é condicionar a alma humana, mesmo que se possa fazê-lo com o corpo.

Se resiste, os soldados atiram, é um homem morto; se cede, degrada-se, não é mais um homem; a vergonha e o temor vão fender-lhe o caráter, desintegrar-lhe a personalidade. A coisa é conduzida a toque de caixa, por peritos: não é de hoje que datam os serviços psicológicos. Nem a lavagem cerebral. E no entanto, malgrado tantos esforços, o objetivo não é atingido em parte nenhuma: no Congo, onde cortavam as mãos dos negros, nem em Angola onde, bem recentemente, furavam-se os lábios dos descontentes para os fechar com cadeados. E não afirmo que seja impossível converter um homem num animal; digo que não se chega a tanto sem o enfraquecer consideravelmente; as bordoadas não bastam, é necessário recorrer à desnutrição. (SARTRE in FANON, 1979, p. 9)

A essas palavras, faz-se mister interpor um antológico poema de Craveirinha, "Grito Negro", em que se expõe nitidamente a revolta contra o processo de aculturação e de submissão política:

Eu sou carvão!

E tu arrancas-me brutalmente do chão.

E fazes-me tua mina

Patrão

Eu sou carvão!

E tu acendes-me, patrão

Para te servir eternamente como força motriz

Mas eternamente não

Patrão! 
Eu sou carvão!

Eu tenho de arder, sim

E queimar tudo com força da minha combustão

Eu sou carvão!

Tenho que arder na exploração

Arder até às cinzas da maldição

Arder vivo como alcatrão, meu irmão

Até não ser mais tua mina

Patrão!

Eu sou carvão!

Tenho que arder

E queimar tudo com o fogo da minha combustão

Sim!

Eu serei o teu carvão

Patrão!

(CRAVEIRINHA, 2010, p. 15)

A metáfora do carvão, muito para além de lembrar o matiz comum ao negro, traz à tona com força a sua situação. Em primeiro plano, Craveirinha com a metáfora expõe sua posição como energia que faz o mundo (imposto como) branco girar, funcionar. Ele é a mão-de-obra. Bem como o carvão aceso mantém o motor das máquinas funcionando, mantém aceso o fogo que aquece, que coze; seu povo mantém a sociedade funcionando, avançando. Assim como o carvão, também, que se arranca da mina, seu povo fora arrancado de sua terra, sob mentira e força bruta, para manter a Europa e o restante do Ocidente.

Craveirinha anuncia que deverá sim arder, até a exaustão, em menção direta à não passividade necessária à transformação. Sim, não parece ser pacífico o caminho até à maturidade para que se alcance, quem sabe, a profecia utópica anunciada no "Poema do futuro cidadão". É necessário o levante, o combate entre olhares, a tomada de posição. Nesse sentido, Sartre é categórico: "nenhuma suavidade apagará as marcas da violência; só a violência é que pode destruí-las" (SARTRE in FANON, 1979, p. 14). E esse ponto de vista é outra vez corroborado pelo poeta, quando anuncia das profundezas:

Possessos de sangue

em abrenúncios

de gritos

Ao rosnar

da súcia,

em de profundis de facas.

(CRAVEIRINHA, 2010, p. 106)

Em "De profundis", José Craveirinha parece evocar a impassividade a estourar, a revolta sufocada no íntimo de seu povo. A expressão de profundis é colhida da Bíblia, do salmo 130, usualmente proferido em ceri- 
mônias aos mortos: Das profundezas clamo por ti, Ó meu Deus... A citação já se habitua ao senso comum há bastante tempo e dá início ao cântico bíblico. Portanto, ao usar tal expressão, o poeta suscita um ânimo interior, um estado de alma, portanto (não pacífico) evoca esse estado de morte com a imposição de facas, como um prenúncio de guerra: da dor de seu povo, submerso, emerge a guerra contra a supressão de seu âmbito cultural e social.

Tal situação, porventura, ocasiona-se de uma querela a que não se vê um fim acordado por simples aperto de mão. Já que o que a faz viva é, de um lado, o desejo colonizador de manter sua superioridade, bem como o seu medo de a perder, e, de outro, o desejo do colonizado de subir ao local do colonizador. Mais uma vez, Homi K. Bhabha, mediante Frantz Fanon, avalia essa situação:

Cada vez que o encontro com a identidade ocorre no ponto em que algo extrapola o enquadramento da imagem, ele escapa à vista, esvazia o eu como lugar da identidade e da autonomia e - o que é mais importante - deixa um rastro resistente, uma mancha do sujeito, um signo de resistência. Já não estamos diante de um problema ontológico do ser, mas de uma estratégia discursiva do momento da interrogação, um momento em que a demanda pela identificação torna-se, primariamente, uma reação a outras questões de significação e desejo, cultura e política. (BHABHA, 1998, p. 83 e 84)

Ora, diante das palavras de Bhabha, compreende-se por que é tão difícil que ambos, colonizado e colonizador, passem por um processo de pacificação, visto que há um constante resguardo entre os dois, um constante sentimento de ataque e de defesa. Se a identificação dos contraditos, sua identidade, se dá pelo lócus enunciativo, se esse local em que se afirmam, cada um de seu lado, é que lhes assegura sua posição, seu eu - dessa forma, não há resolução, visto que a dissolução da desigualdade causa instantaneamente a derrota de um pelo outro, ou a derrota de ambos. A manutenção, pois, dessa desigualdade é que lhes confere identidade.

não o eu e o outro, mas a alteridade do eu inscrita no palimpsesto perverso da identidade colonial. [...]

existir é ser chamado à existência em relação a uma alteridade, seu olhar ou lócus. [...] É sempre em relação ao lugar do outro que o desejo colonial é articulado: o espaço fantasmático da posse, que nenhum sujeito pode ocupar sozinho ou de modo fixo e, portanto, permite o sonho da inversão dos papéis. [...]

é uma imagem duplicadora, dissimuladora do ser em pelo menos dois lugares ao mesmo tempo, que torna impossível para o évolué desvalorizado, insaciável (um abandono neurótico, afirma Fanon) aceitar o convite do colonizador à identidade: "Você é um médico, escritor, um estudante, você é diferente, você é um de nós." (BHABHA, 1998, p. 75 e 76) 
A convivência, assim, torna-se deveras impossível. E a finalidade dessa convivência se materializa na guerra. Não há mais apenas um desejo consciente de vingança. O que se apresenta é um ranço contínuo, um mau olho, como o próprio Bhabha fala, que os norteia. E o desejo de inversão dos papéis torna-se um desejo de realização pessoal, de consumação, ao colonizado:

Se me visses morrer

os milhões de vezes que nasci

Se me visses chorar

os milhões de vezes que te riste...

Se me visses gritar

os milhões de vezes que me calei...

Se me visses cantar

os milhões de vezes que morri

e sangrei...

Digo-te irmão europeu

havias de nascer

havias de chorar

havias de cantar

havias de gritar

E havias de sofrer

a sangrar vivo

milhões de mortes como Eu!!!

(CRAVEIRINHA, 2010, p. 27).

A "Cantiga do batelão", que certamente se refere aos navios negreiros, vem propor essa inversão, embora não pela espada em si, mas em face ao reconhecimento do outro como semelhante: digo-te irmão europeu. Note-se que nesse verso não há indicação de apóstrofe ou vocativo, que seria demarcado com inserção de uma vírgula após digo-te. Dessa maneira, confunde-se o verso (tendo em vista que o poema prima pela ausência de pontuação interna às estrofes), significando, ademais, algo como "digo que tu és meu irmão da Europa", afirmando a irmandade. Se o europeu, pois, entendesse essa fraternidade e se colocasse no lugar de seu povo africano, pudera viver as mesmas sensações e sentimentos por que passavam. Ainda é possível supor, psiquicamente implícito, um desejo rancoroso de retorno, devolução, vingança, - quase como um carma, numa previsão de reconhecimento frente à posição identitária de seu povo negro, o qual padece em sofrimento, - encerrando-se no "Eu" capital que fecha o poema (fazendo com que todos os versos desemboquem nesse "Eu" afirmativo da identidade, enfatizando seu direito cidadão). E isso fosse necessário, ou única solução diante do infortúnio do racismo, quando o que é legado ao negro é somente o descaso, não lhe admitindo jamais a cidadania: 


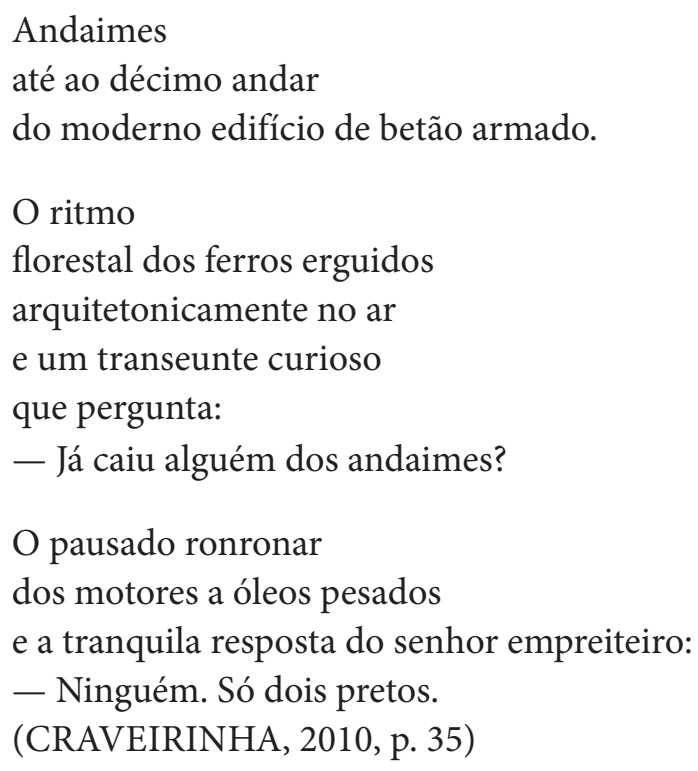

É, pois, diante de tais mazelas que emerge a voz do levante contra a colônia, já em 1964 inevitável a Moçambique e irreprimível:

Na cidade calada à força agora falamos mais.

Que para violar este silêncio basta porem-nos juntos na prisão.

(CRAVEIRINHA, 2010 p. 82)

Pois, para eles, só lhes é deixado haver o que a Portugal é correto deixar-lhes:

vendem-me $[. .$.

a vergonha de uma certidão de filho de pai incógnito uma educativa sessão de "strip-tease" e meio litro de vinho tinto com graduação de álcool de branco exacta só para negro (CRAVEIRINHA, 2010, p. 16)

Ora, então, nem o que lhes seria habitual não lhes pode ser mais. É o branco que lhes indica como viver, o que tomar, como desfrutar seus prazeres. Impedindo o curso natural de sua vida, ignorando em absoluto sua posição, seu passado, sua realidade. Retornando à ideia de pecado, consideram-lhes um povo a ser salvo, corrigido pela civilização:

mas já não ouvem a subtil voz das árvores nos ouvidos surdos do espasmo das turbinas não leem nos meus livros de nuvens o sinal das cheias e das secas e nos seus olhos ofuscados pelos clarões metalúrgicos extinguiu-se a eloquente epidérmica beleza de todas as cores das flores do universo e já não entendem o gorjeio romântico das aves de casta instintos de asas em bando nas pistas do éter infalíveis e simultâneos bicos trespassando sôfregos a infinita côdea impalpável de um céu que não existe. (CRAVEIRINHA, 2010, p. 18) 
A isso tudo que habita a alma do poeta, chamam-no primitivo, pois não se lhe atribui progresso, civilidade. Ao que se atribui evolução em sua concepção de mundo é que veneram. Portanto, Craveirinha é genial ao pôr em xeque tal conceituação:

E aprendo que os homens que inventaram
a confortável cadeira eléctrica
a técnica de Buchenwald e as bombas V2
acenderam fogos de artifício nas pupilas
de ex-meninos vivos de Varsóvia
criaram Al Capone, Hollywood, Harlem
a seita Ku-Klux-Klan, Cato Mannor e Sharpeville
e emprenharam o pássaro que fez o choco
sobre o ninho morno de Hiroshima e Nagasaki
conheciam o segredo das parábolas de Charlie Chaplin
leem Platão, Marx, Gandhi, Einstein e Jean-Paul Sartre
e sabem que Garcia Lorca não morreu mas foi
assassinado
são os filhos dos santos que descobriram a Inquisição
perverteram de labaredas a crucificada nudez
da sua Joana D’Arc e agora vêm
arar os meus campos com charruas "made in Germany”
(CRAVEIRINHA, 2010, p.17)

Se, diante de todo o conhecimento civilizado, de todo o acúmulo de conhecimento, de perpetração de sua tradição; se diante de tudo isso esse homem é capaz de tais atrocidades, nos versos citados, então o que faz o conceito de civilização sobpor a sua primitividade? Confrontam-se assim o civilizado e o primitivo. E já não estamos ilesos ao crer que seja aquele estado superior a este. Diante desse disparate, ainda uma vez se clama a empresa burguesa cinematográfica hollywoodiana, com a proposição da seguinte imagem: "um filme de heróis de carabina a vencer traiçoeiros/ selvagens armados de penas e flechas" (CRAVEIRINHA, 2010, p. 17). Imagem que recobra séculos de um imaginário imposto, o qual propõe novamente a antítese entre o selvagem e o bom mocinho, a manutenção do preconceito que delega ao indígena e ao negro a ignorância, admitindo e enfatizando, como uma necessidade, o etnocídio:

Aceita-se que o etnocídio é a supressão das diferenças culturais julgadas inferiores e más; é a aplicação de um princípio de identificação, de um projeto de redução do outro ao mesmo (o índio amazônico suprimido como outro e reduzido ao mesmo como cidadão brasileiro). (CLASTRES, 2011, p. 83)

Essa violência destilada sobre os povos "não civilizados", dessa forma, não é facilmente absolvida, abandonada por quem, mesmo não vivendo diretamente as mazelas, sobrevive delas para proliferar o futuro:

E no colo macio das ondas não adivinham os vermelhos sulcos das trilhas negreiras e não sentem como eu sinto o prenúncio mágico sob os transatlânticos da cólera das catanas ${ }^{4}$ de ossos nos batuques do mar.

(CRAVEIRINHA, 2010, p. 18) 
E, definitivamente, Craveirinha coloca seu grito ao alto sem retroceder, anunciando que desde ali se inicia a inversão, a postura de guerra, o abrenúncio da revolução! Pois em seu povo vive a força pagã primitiva, o poder da terra e dos seus deuses naturais, que inundam de força e de mansidão o seu coração. A natureza tribal de sua terra ressurge como firma de identidade e aviso aos colonizadores...

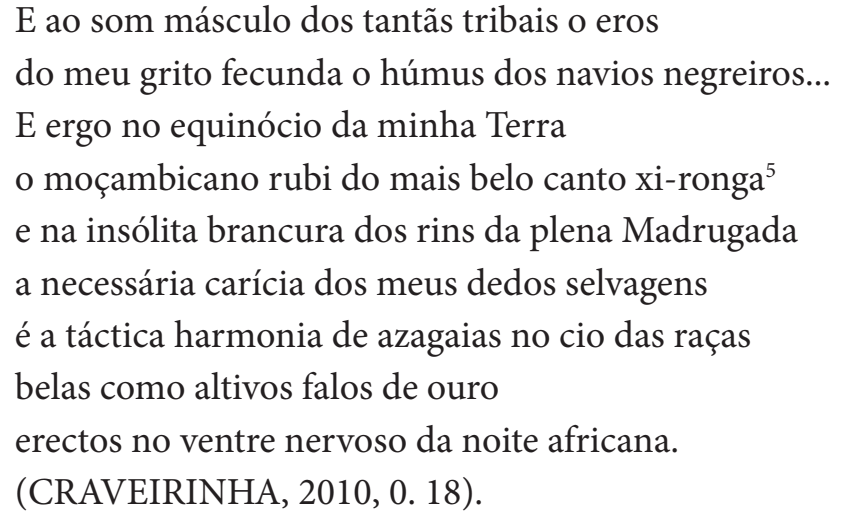

De qualquer forma, a dicotomia entre guerra e paz se lhe reafirma mesmo em "África", mesmo em seu momento de desconcerto, de brado, de retorno, de violência. Como se ao poeta não fosse dado apenas pensar a revolta, viver a realidade, mas sonhar com um momento transcendente, em que tudo se resolvesse, em que a humanidade vivesse em comunidade, juntos, como filhos do mesmo lar, em harmonia:

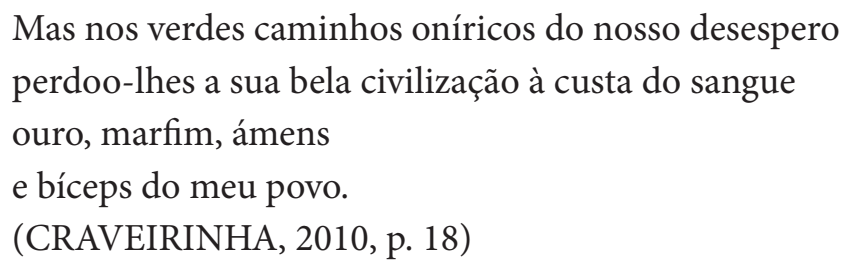

\section{REFERÊNCIAS BIBLIOGRÁFICAS}

BHABHA, Homi K. O local da cultura. Belo Horizonte: Editora UFMG, 1998.

CLASTRES, Pierre. Arqueologia da violência: pesquisas de antropologia política. São Paulo: Cosac Naify, 2011.

CRAVEIRINHA, José. Antologia poética. Organização de Ana Mafalda Leite. Belo Horizonte: Editora da UFMG, 2010.

ELIAS, Norberto. O processo civilizador. Rio de Janeiro: Jorge Zahar Editor, 1990.

FANON, Frantz. Os condenados da terra. Rio de Janeiro: Civilização Brasileira, 1979.

MIGNOLO, Walter D. La Idea de América Latina. Barcelona: Editorial Gedisa, 2005. 


\section{NOTAS}

1 "Na verdade, a consciência crioula era sim uma dupla consciência: a de não ser o que se supunha que deviam ser (isto é, europeus). Esse ser que é na verdade um não-ser é a marca da colonialidade do ser. Os crioulos afrodescendentes e os aborígenes não têm esse problema. Em seu caso, a consciência crítica surge de não ser considerados nem sequer humanos." (Tradução minha)

2 Xibugo é nome dado a uma dança nativa moçambicana.

3 Houve a interpretação intencionada de que, no episódio de Gênesis 9, 18-29, Cam, filho de Noé expulso por ver a nudez proibida do pai, fosse negro, o que justificaria a escravidão. Em nota de rodapé à edição Pastoral da Bíblia Sagrada, assim se explica: "Cam é o antepassado dos cananeus, adversários ferrenhos de Israel. A maldição de Cam foi abusivamente interpretada na história como maldição da raça negra." (Bíblia Sagrada: Edição pastoral. 35. ed. São Paulo: Paulus, 1999.).

4 Catana: espécie de facão.

5 Xi-ronga: língua nativa moçambicana. 